Supporting Information for

\title{
An Activatable Photoacoustic Probe for In Situ Imaging of Endogenous Carbon Monoxide in Murine Inflammation Model
}

Wenxiu Li, Rong Li, Rui Chen, Xing Liang, Wenhui Song, Weiying Lin*

Guangxi Key Laboratory of Electrochemical Energy Materials, Institute of Optical Materials and Chemical Biology, School of Chemistry and Chemical Engineering, Guangxi University, Nanning, Guangxi 530004, P. R. China

E-mail: weiyinglin2013@163.com 


\section{Table of contents}

Page

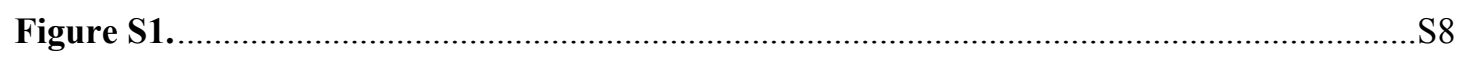

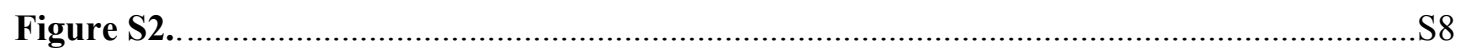

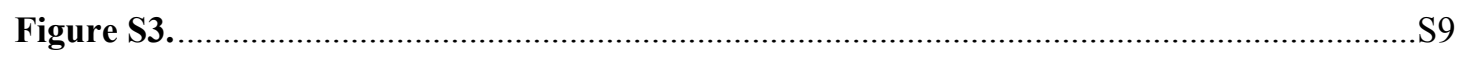

Figure S4 .

Figure S5.

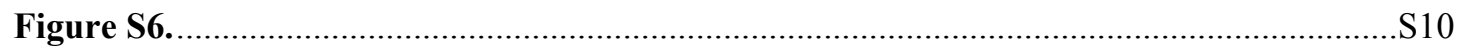

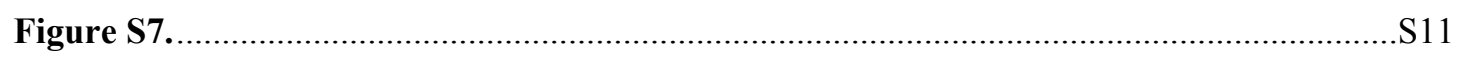

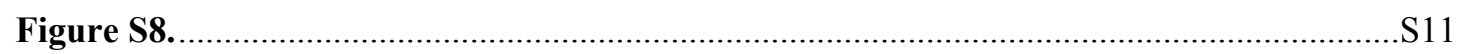

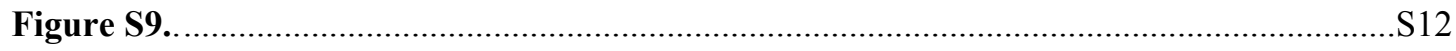

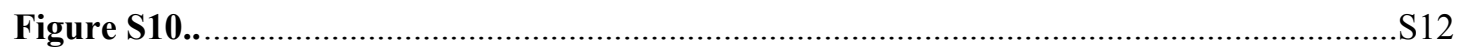

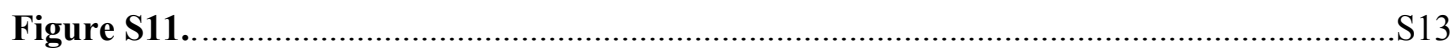

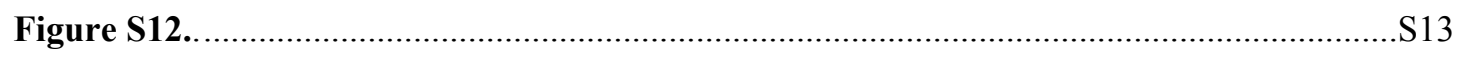

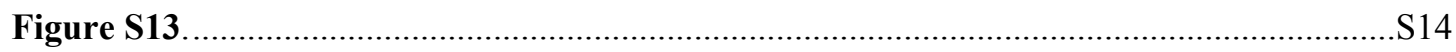

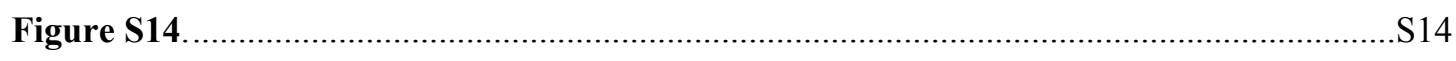

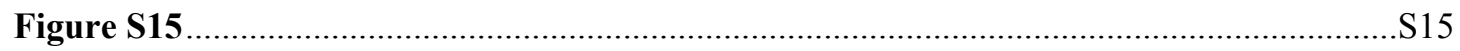

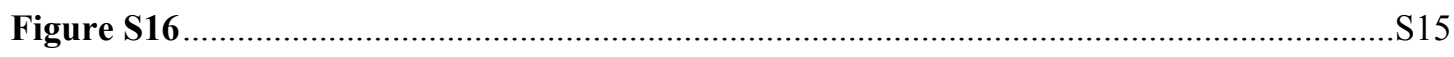

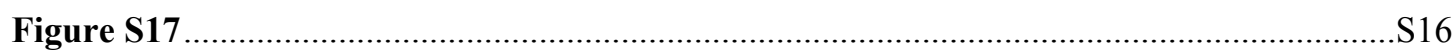

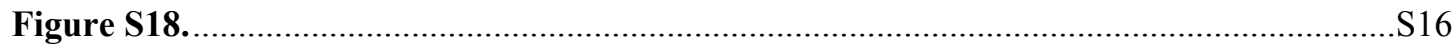

Figure S19.

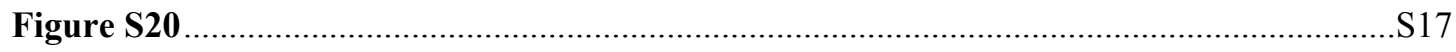

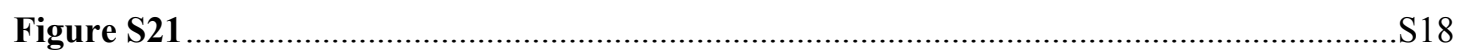




\section{Materials and instruments}

All chemicals and reagents were obtained from commercial suppliers unless otherwise stated. All experiments used ultra-pure water. ${ }^{1} \mathrm{H}$ NMR and ${ }^{13} \mathrm{C}$ NMR spectra were obtained on a Bruker Avance III HD $500 \mathrm{MHz}$ NMR spectrometer (Germany). High resolution mass spectrometric (HRMS) analyses were measured on Aglient 6550 Q-TOF. The absorbance was recorded by ultraviolet-visible absorption spectrometry (UV-2700, Shimadzu) or microplate reader (TransGen Biotechnology). All optoacoustic measurements were performed by using a LOIS 3D imaging system (TomoWave Laboratories, and USA) was employed for PA imaging. TLC analysis carried out on silica gel plates and column chromatography was conducted over silica gel (mesh 200-300), both of them were purchased from the Qingdao Ocean Chemicals. All aqueous solutions were prepared withultrapure water obtained from a Milli-Q water purification system $(18.2 \mathrm{M} \Omega \mathrm{cm})$

\section{Cell culture and in vitro cytotoxicity test}

The cytotoxicity of MTR-CO was evaluated on HeLa cells (Human Cervical Adenocarcinoma Epithelial Cells). HeLa cells were cultured in Dulbecco's modified Eagle's medium (DMEM) supplemented with $10 \%$ fetal bovine serum (FBS), $100 \mathrm{U} / \mathrm{mL}$ penicillin and $100 \mu \mathrm{g} / \mathrm{mL}$ streptomycin with an atmosphere of $5 \% \mathrm{CO}_{2}$ at $37^{\circ} \mathrm{C}$. Cells were seeded in $96-$ well plates $\left(5 \times 10^{3}\right.$ cells/well) and incubated for $24 \mathrm{~h}$, and then MTR-CO (final concentration 0, 2.5, 5, $10,20,30$, and $50 \mu \mathrm{mol} / \mathrm{L}$ ) was added to the cell culture medium. The cells were treated with CCK-8 (cell-counting Kit-8) at $37{ }^{\circ} \mathrm{C}$ for $4 \mathrm{~h}$. The absorbance at $450 \mathrm{~nm}$ was measured using a microplate reader (TransGen Biotechnology, China). The cellular viability of each group was determined by defining the absorbance of the controls group to be $100 \%$ viability. The assays were performed in six sets for each concentration.

\section{In vivo toxicity assessment of MTR-CO probe}

Two groups of BALB/c nude mice were injected with $100 \mu \mathrm{L}$ saline (control group) or normal saline $(100 \mu \mathrm{L})$ containing MTR-CO $(30 \mu \mathrm{M})$ through the tail vein to evaluate systemic toxicity. Then, measure the weight of the mice every day for 10 consecutive days and check for clinically relevant abnormalities.

4. $\mathrm{PA}$ imaging of exogenous $\mathrm{CO}$ in vivo

The female BALB/c nude mice were randomly divided into two groups $(\mathrm{n}=3$ for each 
group). The first group received $30 \mu \mathrm{M}$ MTR-CO solutions (containing $30 \mu \mathrm{M} \mathrm{PdCl}_{2}$ ); the second group received a subcutaneous injection of $10 \mu \mathrm{M} \mathrm{ZnPP}$ for $24 \mathrm{~h}$, and then received by $30 \mu \mathrm{M}$ of MTR-CO (containing $30 \mu \mathrm{M} \mathrm{PdCl}_{2}$ ) solution. The third group received a subcutaneous injection of $30 \mu \mathrm{M}$ MTR-CO (containing $30 \mu \mathrm{M} \mathrm{PdCl}_{2}$ ) solution, followed by $180 \mu \mathrm{M}$ of CORM-3 solution. For time-dependent PA imaging in vivo, the female BALB/c nude mice were anesthetized and set on the multispectral optoacoustic tomography scanner (LOIS-3D, TomoWave Laboratories, and USA). After data acquisition, the PA images were reconstructed using a standard backprojection algorithm.

\section{Synthesis of compounds}

\section{Synthesis route of the PA probe MTR-CO}
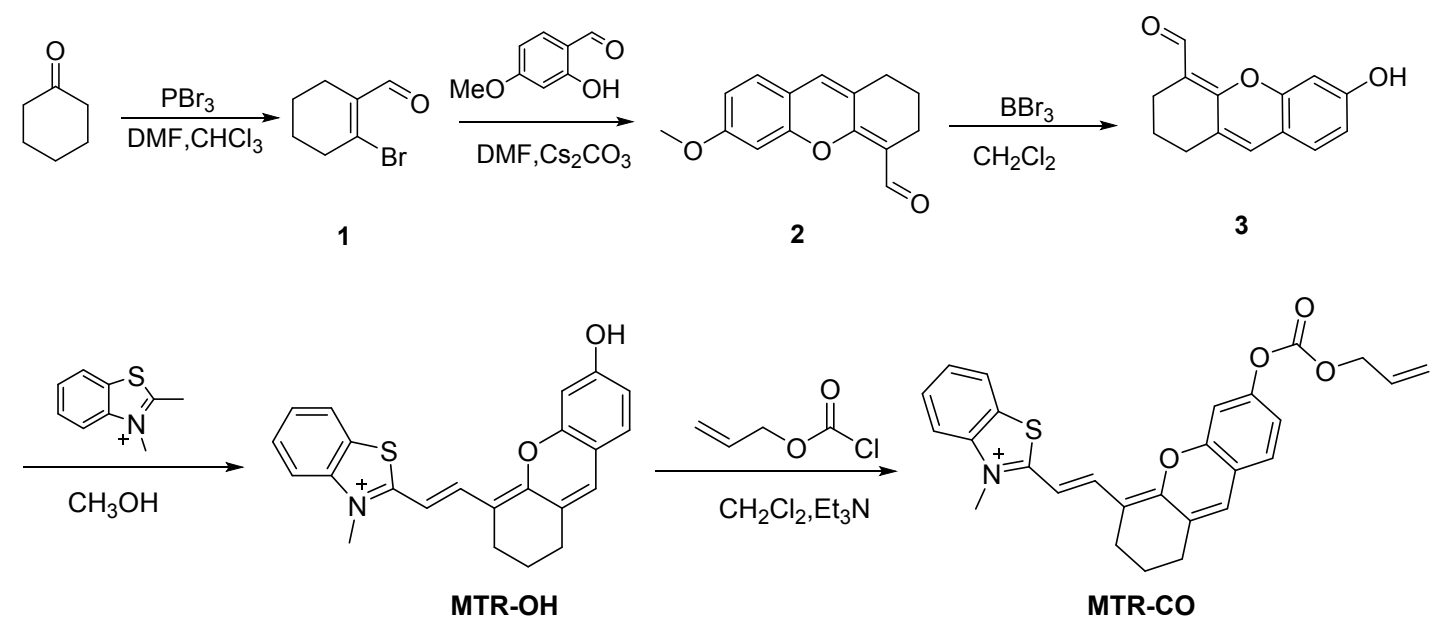

Scheme S1. Synthesis route of probe MTR-CO

\subsection{Synthesis of compound 1}

To a mixture of chloroform $(30 \mathrm{~mL})$ and $\mathrm{DMF}(5.5 \mathrm{~mL})$ was slowly added $\mathrm{PBr}_{3}(6 \mathrm{~mL})$ at $0{ }^{\circ} \mathrm{C}$, and the mixture was stirred for $45 \mathrm{~min}$, cyclohexanone $(5 \mathrm{~mL})$ was added and the resulting solution was continued stirring at $25^{\circ} \mathrm{C}$ for $12 \mathrm{~h}$. After that, the solution was poured into $20 \mathrm{~mL}$ ice water and then then neutralized with $\mathrm{NaHCO}_{3}$. The aqueous solution was poured into $\mathrm{CH}_{2} \mathrm{Cl}_{2}$ and washed three times with saturated brine. Subsequently, the organic layer was dried over anhydrous $\mathrm{Na}_{2} \mathrm{SO}_{4}$ and evaporated to give a yellow oil compound $1(3 \mathrm{~g})$.

\subsection{Synthesis of compound 2}

A mixture of Compound 1 (0.94 g, $5 \mathrm{mmol})$, 4-methoxysalicylaldehyde $(0.76 \mathrm{~g}, 5 \mathrm{mmol})$, $\mathrm{Cs}_{2} \mathrm{CO}_{3}(0.98 \mathrm{~g}, 3 \mathrm{mmol})$ in dry $3 \mathrm{~mL}$ DMF was stirred for 6 hours at $25^{\circ} \mathrm{C}$. Water was added to 
the reaction solution, and was extracted with $\mathrm{CH}_{2} \mathrm{Cl}_{2}$. The combined organic phases were dried over anhydrous $\mathrm{Na}_{2} \mathrm{SO}_{4}$ and filtered. After removing solvent, the crude product was purified to silica chromatography with PE:AcOEt $(9: 1, \mathrm{v} / \mathrm{v})$ as eluent to afford a yellow solid compound 2 (0.94 g, yield 78\%). ${ }^{1} \mathrm{H}$ NMR (500 MHz, $\left.\mathrm{CDCl}_{3}\right) \delta 10.34-10.21(\mathrm{~m}, 1 \mathrm{H}), 7.11-7.02(\mathrm{~m}, 1 \mathrm{H})$, $6.65(\mathrm{dd}, J=5.2,1.7 \mathrm{~Hz}, 3 \mathrm{H}), 3.88-3.76(\mathrm{~m}, 3 \mathrm{H}), 2.55(\mathrm{~d}, J=4.9 \mathrm{~Hz}, 2 \mathrm{H}), 2.48-2.38(\mathrm{~m}, 2 \mathrm{H})$, $1.79-1.61(\mathrm{~m}, 2 \mathrm{H}) .{ }^{13} \mathrm{C}$ NMR $\left(126 \mathrm{MHz}, \mathrm{CDCl}_{3}\right) \delta 187.46,161.41,160.96,160.91,153.38$, $127.48,127.06,127.02,126.57,114.68,112.53,110.97,110.92,100.48,55.67,29.93,21.53$, 20.40 .

\subsection{Synthesis of compound 3}

To a solution of Compound $2(1.21 \mathrm{~g}, 5 \mathrm{mmol})$ in $10 \mathrm{~mL}$ of anhydrous $\mathrm{CH}_{2} \mathrm{Cl}_{2}, \mathrm{BBr}_{3}(0.75$ $\mathrm{mL}$ ) was added dropwise at $0{ }^{\circ} \mathrm{C}$. The mixture was warmed to $25^{\circ} \mathrm{C}$ and stirred for $12 \mathrm{~h}$. The reaction solution was quenched by adding ice water. After filtration, the crude product was purified to silica gel chromatography with $\mathrm{CH}_{3} \mathrm{OH}: \mathrm{CH}_{2} \mathrm{Cl}_{2}(1: 20$, v/v) as eluent; as a result, an orange solid Compound 3 was obtained (0.93 g, yield 82\%). ${ }^{1} \mathrm{H}$ NMR (500 MHz, DMSO) $\delta 10.17$ (d, $J=4.1 \mathrm{~Hz}, 1 \mathrm{H}), 7.17$ (dd, $J=8.1,4.6 \mathrm{~Hz}, 1 \mathrm{H}), 6.89$ (d, $J=6.9 \mathrm{~Hz}, 1 \mathrm{H}), 6.63-6.53(\mathrm{~m}, 1 \mathrm{H})$, $2.56-2.46(\mathrm{~m}, 1 \mathrm{H}), 2.28(\mathrm{dd}, J=8.0,3.5 \mathrm{~Hz}, 1 \mathrm{H}), 1.65-1.51(\mathrm{~m}, 1 \mathrm{H}) .{ }^{13} \mathrm{C}$ NMR $(126 \mathrm{MHz}$, DMSO) $\delta 186.55,160.76,160.16,153.19,128.58,128.06,125.15,113.50,112.45,111.74$, $102.32,29.41,21.69,20.47$.

\subsection{Synthesis of compound MTR-OH}

A mixture of Compound 3 (0.114 g, $0.5 \mathrm{mmol})$, 3- methyl-2-methylbenzo[d]thiazol-3-ium $(0.156 \mathrm{~g}, 0.5 \mathrm{mmol})$ in $10 \mathrm{~mL}$ anhydrous ethanol was stirred at $78^{\circ} \mathrm{C}$ for $10 \mathrm{~h}$. Then, the solution was cooled to room temperature and filtered to obtain solid. The residue was subjected to silica gel chromatography with $\mathrm{CH}_{2} \mathrm{Cl}_{2}: \mathrm{CH}_{3} \mathrm{OH}(50: 1, \mathrm{v} / \mathrm{v})$ as eluent, and a blue solid product was obtained (0.17 g, yield 68\%). ${ }^{1} \mathrm{H}$ NMR (500 MHz, DMSO) $\delta 10.51$ (s, 1H), 8.30 (d, J=13.9 Hz, 1H), $8.23(\mathrm{~d}, J=6.4 \mathrm{~Hz}, 1 \mathrm{H}), 8.04(\mathrm{~d}, J=7.3 \mathrm{~Hz}, 1 \mathrm{H}), 7.75(\mathrm{~s}, 1 \mathrm{H}), 7.64(\mathrm{~s}, 1 \mathrm{H}), 7.34(\mathrm{~d}, J=6.9$ Hz, 1H), 7.23 (s, 1H), 6.87 (d, $J=13.7 \mathrm{~Hz}, 1 \mathrm{H}), 6.81-6.70$ (m, 2H), 4.13 (s, 3H), 2.64 (s, 4H), 1.80 (s, 2H). ${ }^{13} \mathrm{C}$ NMR (126 MHz, DMSO) $\delta 170.38,161.18,158.17,154.21,142.56,142.30$, $131.31,129.13,127.57,126.14,124.07,116.05,113.88,112.24,105.91,102.36,35.52,28.97$, $24.71,20.56$. 


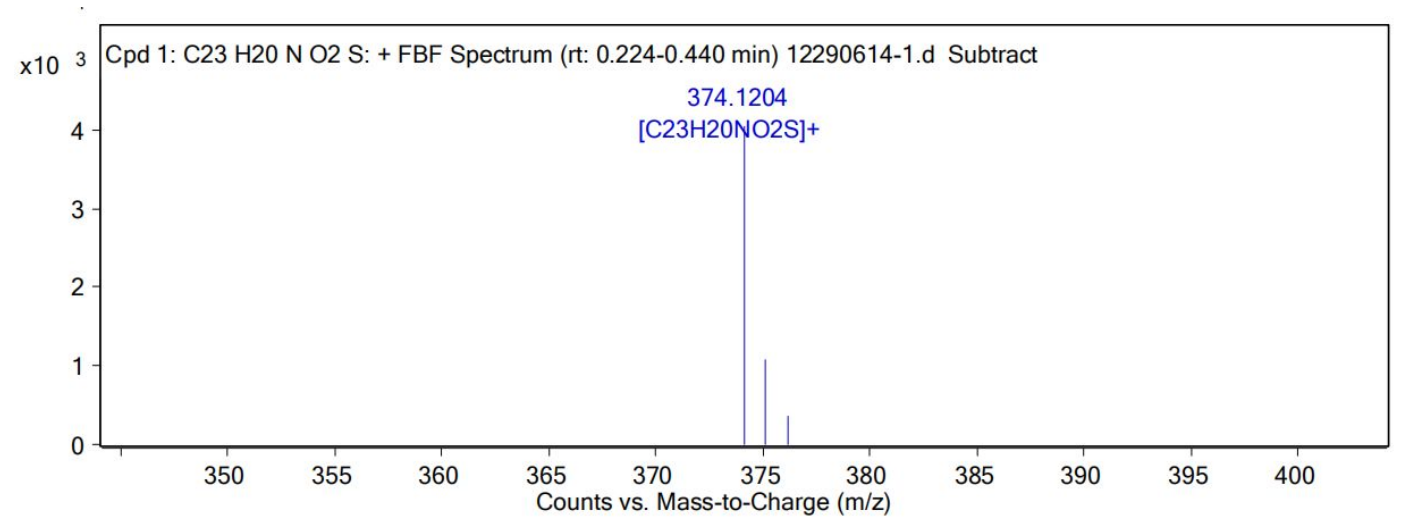

Figure S1. ESI-MS spectrum of MTR-CO with the addition of CORM-3 $(60 \mu \mathrm{M})$

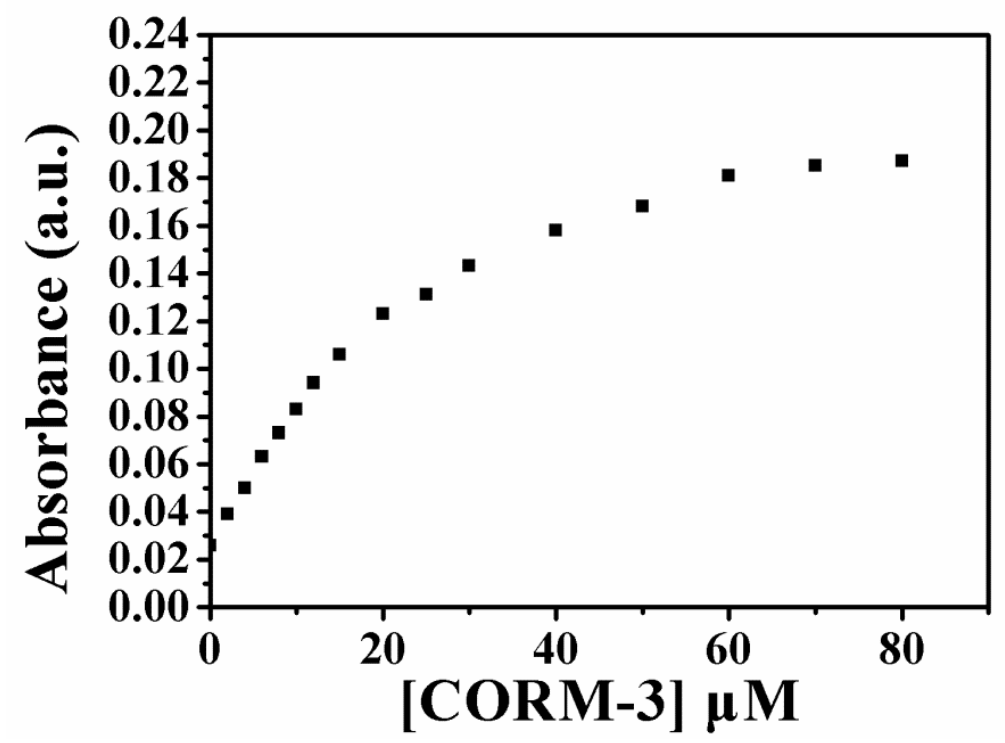

Figure S2. The absorption intensity changes of the probe system (MTR-CO $+\mathrm{PdCl}_{2}, 10 \mu \mathrm{M}$ each) at $690 \mathrm{~nm}$ as a function of the concentration of CORM-3 from 0 to $80 \mu \mathrm{M}$. All spectra were monitored $40 \mathrm{~min}$ after mixing in Tris- $\mathrm{HCl}$ buffer $(25 \mathrm{mM}, \mathrm{pH} 7.4)$ at $25^{\circ} \mathrm{C}$. 


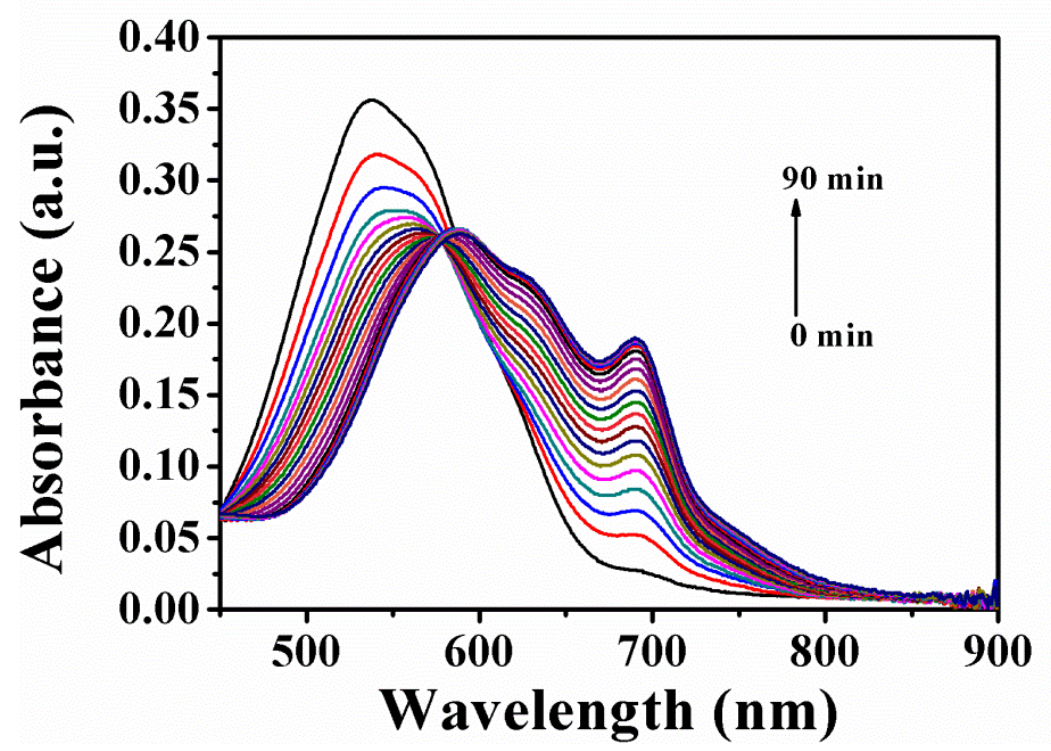

Figure S3. Absorption spectra of $10 \mu \mathrm{M}$ MTR-CO and $10 \mu \mathrm{M} \mathrm{PdCl}_{2}$ upon incubation with CORM-3 $(60 \mu \mathrm{M})$ in Tris- $\mathrm{HCl}$ buffer $(25 \mathrm{mM}, \mathrm{pH}=7.4$, with $5 \%$ DMSO, v/v) at r.t. for $0-90$ $\min$.

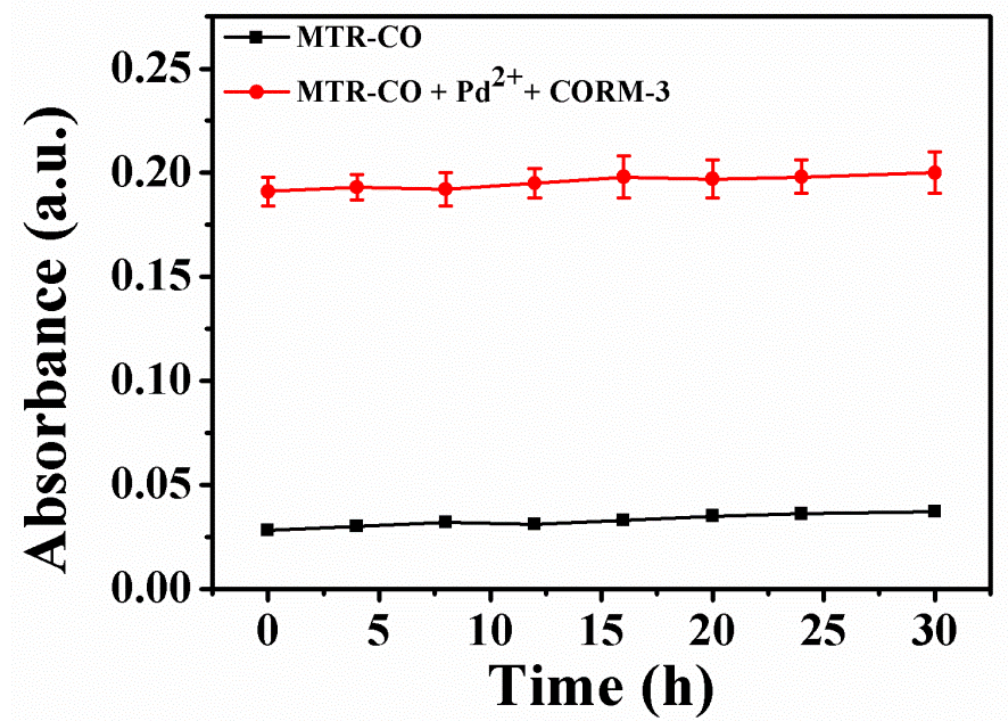

Figure S4. The photostability of probe system (MTR-CO $+\mathrm{PdCl}_{2}, 10 \mu \mathrm{M}$ each) in the absence or presence of CORM-3 $(60 \mu \mathrm{M})$ at the $\mathrm{Abs}_{690}$. The reaction medium was a Tris-HCl buffer solution $(25 \mathrm{mM}, \mathrm{pH} 7.4,5 \%$ DMSO (v/v). Error bars represent mean values \pm SD. $(\mathrm{n}=3)$. 


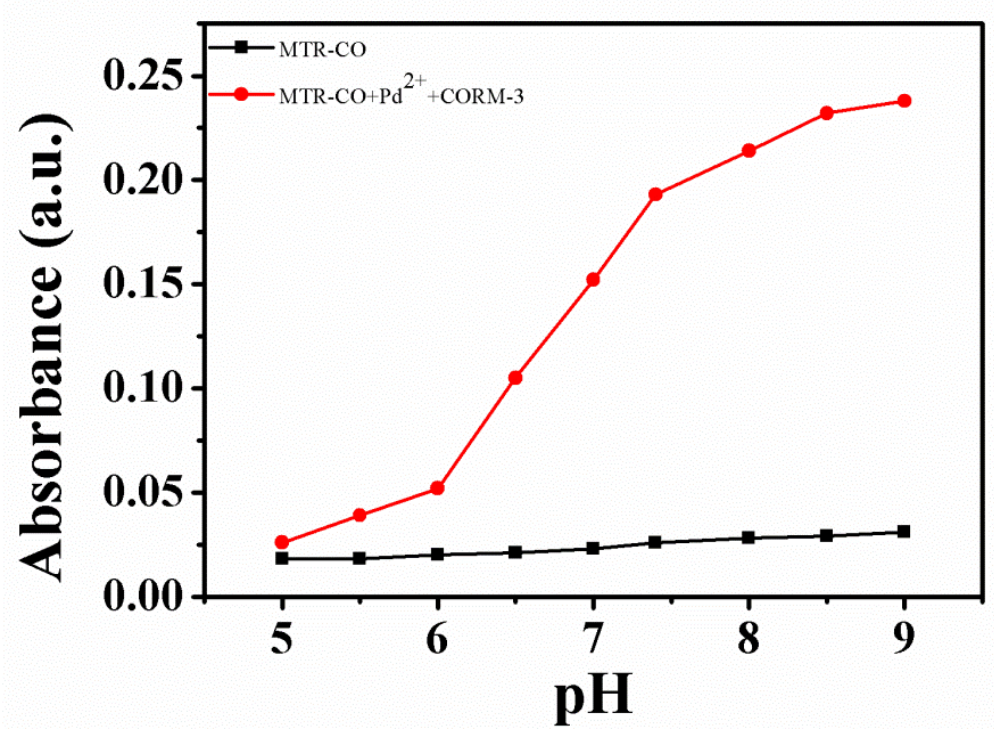

Figure S5. Absorption intensity (690 nm) of $10 \mu \mathrm{M}$ MTR-CO and $10 \mu \mathrm{M} \mathrm{PdCl}_{2}$ toward CORM-3 $(60 \mu \mathrm{M})$ at various $\mathrm{pH}$ values. All spectra were monitored $40 \mathrm{~min}$ after mixing in Tris- $\mathrm{HCl}$ buffer $(25 \mathrm{mM}$, $\mathrm{pH} 7.4,5 \% \mathrm{DMSO})$ at $37^{\circ} \mathrm{C}$.

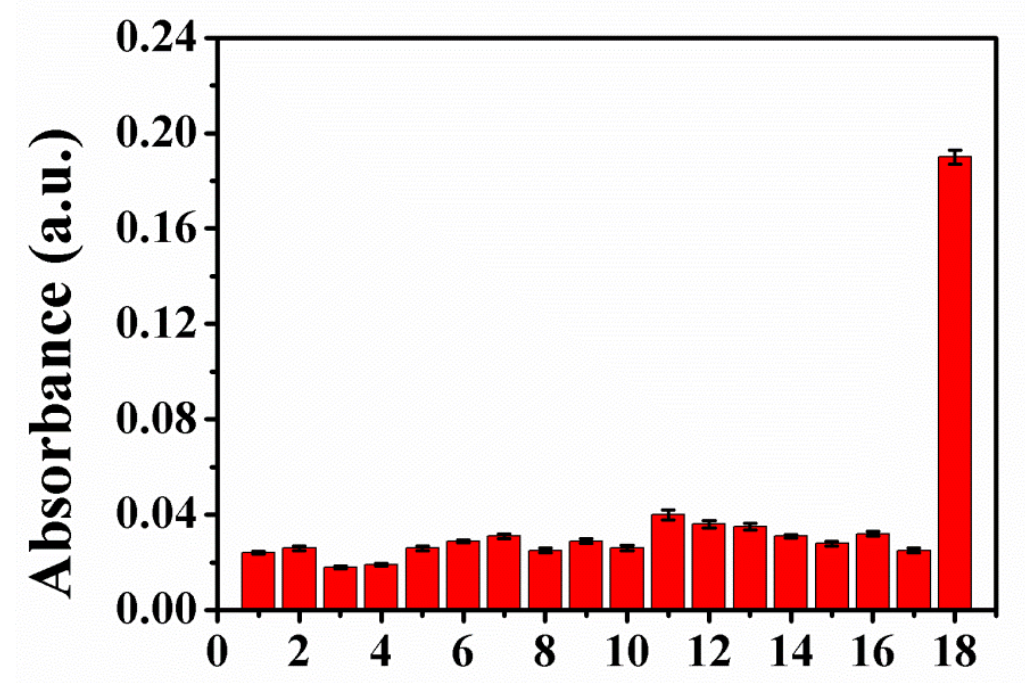

Figure S6. Absorption intensity of probe system (MTR-CO $+\mathrm{PdCl}_{2}, 10 \mu \mathrm{M}$ each) in the presence of CORM-3 (60 $\mu \mathrm{M})$ and other biological analyses. The analytes 1-18: (1) blank, (2) •OH, (3) $\mathrm{ClO}^{-}$, (4) $\mathrm{H}_{2} \mathrm{O}_{2}$, (5) $\mathrm{S}^{2-}$, (6) $\mathrm{SO}_{3}^{2-}$, (7) $\mathrm{SCN}-$, (8) $\mathrm{I}^{-}$, (9) $\mathrm{Fe}^{2+}$, (10) $\mathrm{NO}_{2}^{-}$, (11) Cys, (12) Hcy, (13) GSH, (14) Leu, (15) Trp, (16) Thr, (17) Lys, (18) CORM-3. All spectra were monitored $40 \mathrm{~min}$ after mixing in Tris- $\mathrm{HCl}$ buffer $(25 \mathrm{mM}, \mathrm{pH} 7.4)$ at $25{ }^{\circ} \mathrm{C}$. Error bars represent mean values $\pm \operatorname{SD} .(n=3)$. 


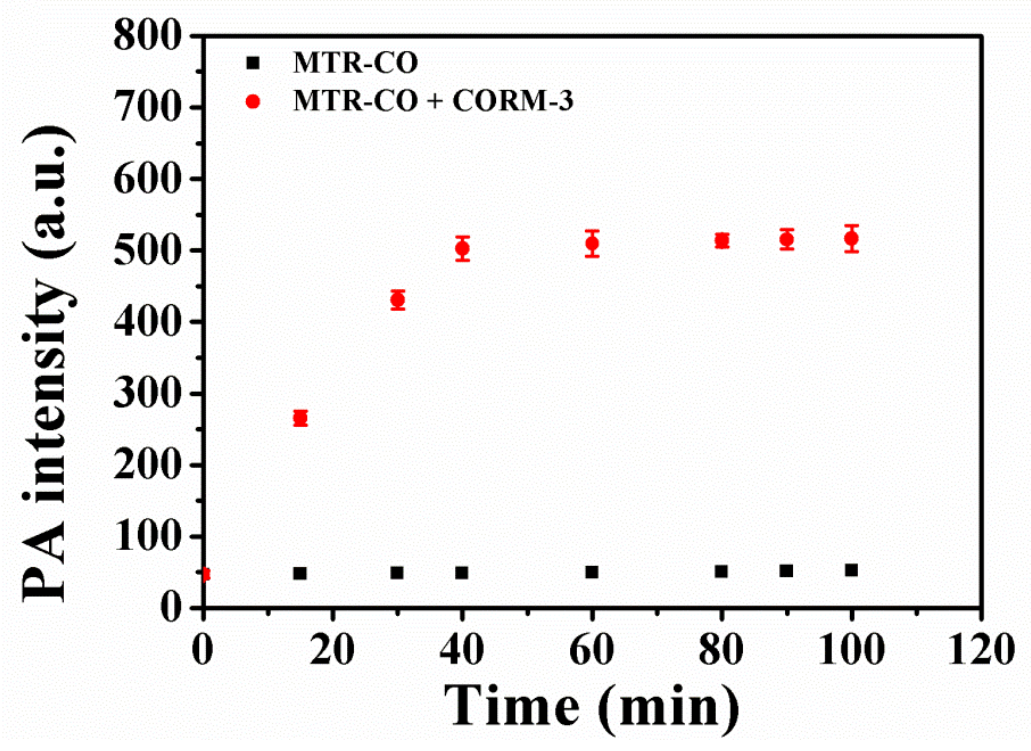

Figure S7. Time-dependent PA intensity of probe system (MTR-CO $+\mathrm{PdCl}_{2}, 30 \mu \mathrm{M}$ each) upon addition of CORM-3 $(180 \mu \mathrm{M})$ at $\mathrm{PA}_{690}$. All spectra were monitored 40 min after mixing in Tris- $\mathrm{HCl}$ buffer $(25 \mathrm{mM}, \mathrm{pH} 7.4)$ at $37^{\circ} \mathrm{C}$. Error bars represent mean values $\pm \mathrm{SD}$. $(\mathrm{n}=3)$.

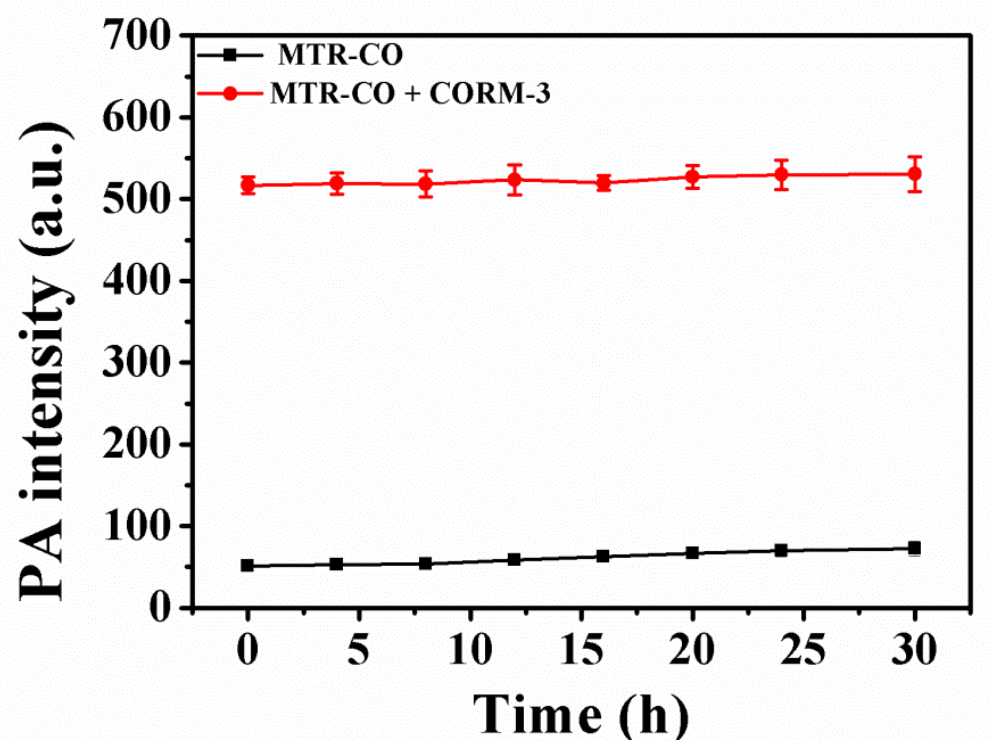

Figure S8. The photostability of probe system (MTR-CO $+\mathrm{PdCl}_{2}, 30 \mu \mathrm{M}$ each) in the absence or presence of CORM-3 $(180 \mu \mathrm{M})$ at $\mathrm{PA}_{690}$. The reaction medium was a Tris-HCl buffer solution (25 $\mathrm{mM}, \mathrm{pH} 7.4,5 \% \mathrm{DMSO}(\mathrm{v} / \mathrm{v})$. Error bars represent mean values $\pm \mathrm{SD} .(\mathrm{n}=3)$. 


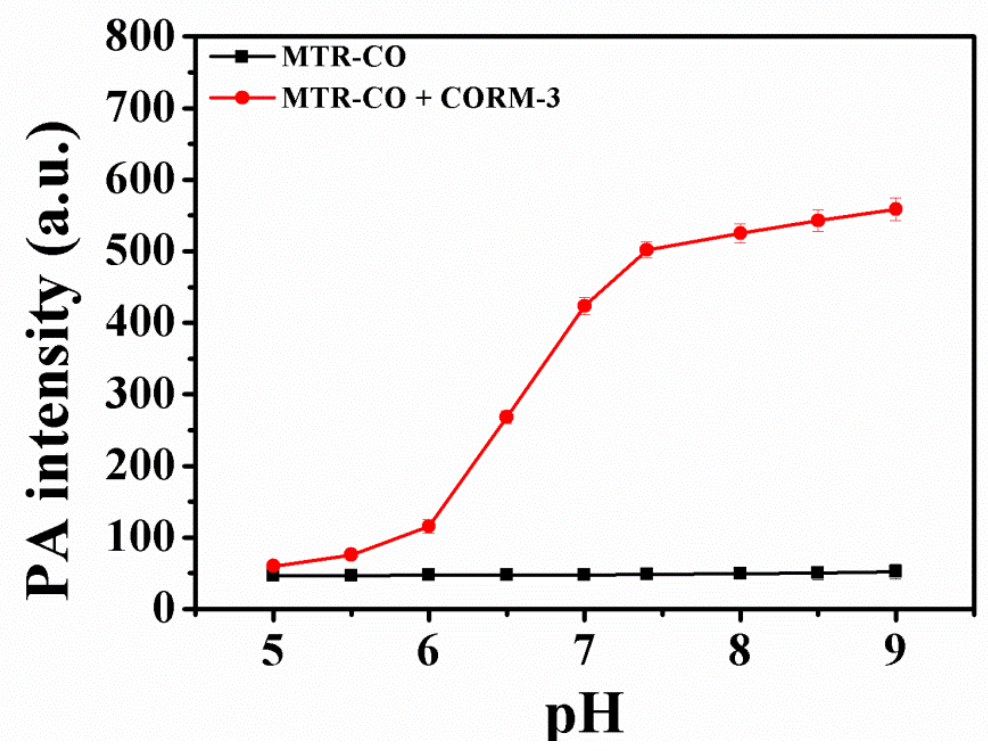

Figure S9. PA intensity $(690 \mathrm{~nm})$ of probe system (MTR-CO $+\mathrm{PdCl}_{2}, 30 \mu \mathrm{M}$ each) toward CORM-3 $(180 \mu \mathrm{M})$ at various $\mathrm{pH}$ values. All spectra were monitored 40 min after mixing in Tris- $\mathrm{HCl}$ buffer $(25 \mathrm{mM}, \mathrm{pH} 7.4,5 \% \mathrm{DMSO})$ at $37^{\circ} \mathrm{C}$.

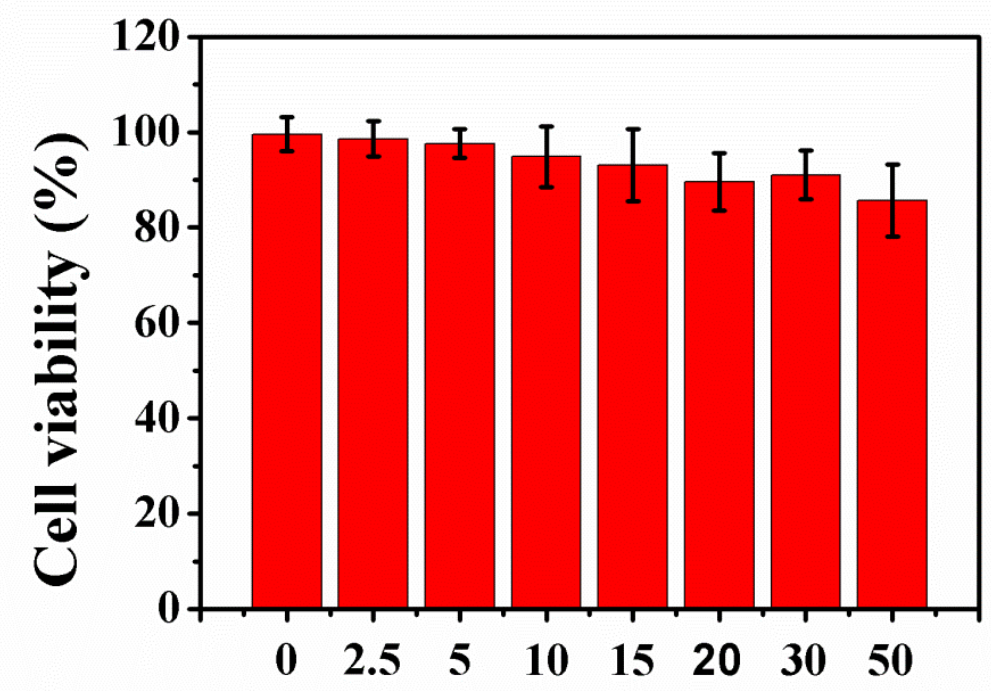

Figure S10. Survival rate of HeLa cells after $24 \mathrm{~h}$ of incubation with different concentrations of MTR-CO. 


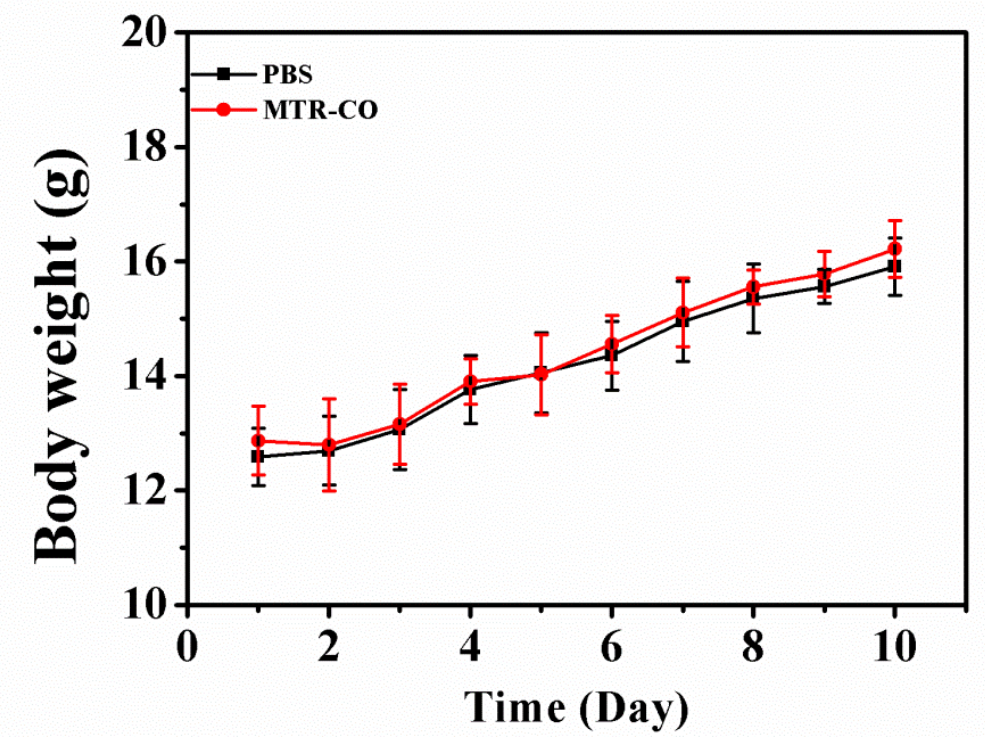

Figure S11. Body weight change of the mice during 10 days following the intravenous injection of PBS (control group) and MTR-CO $(30 \mu \mathrm{M}, 100 \mu \mathrm{L})$ into the tail vein of the mice.

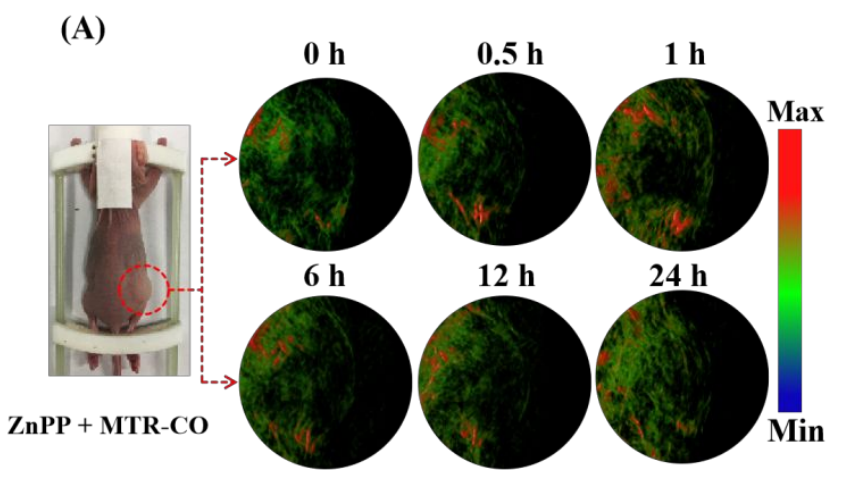

(B)

Figure S12. Time-dependent PA imaging of MTR-CO probe in vivo. (A) The air pouch mice were subcutaneous injected of $\mathrm{ZnPP}(10 \mu \mathrm{M})$ for $24 \mathrm{~h}$ and injected with probe solution (MTR-CO $+\mathrm{PdCl}_{2}, 30 \mu \mathrm{M}$ each). (B) Relative PA intensity of the corresponding PA images in (A). The error bars represent standard deviations $( \pm$ S.D.) of three separate measurements. 


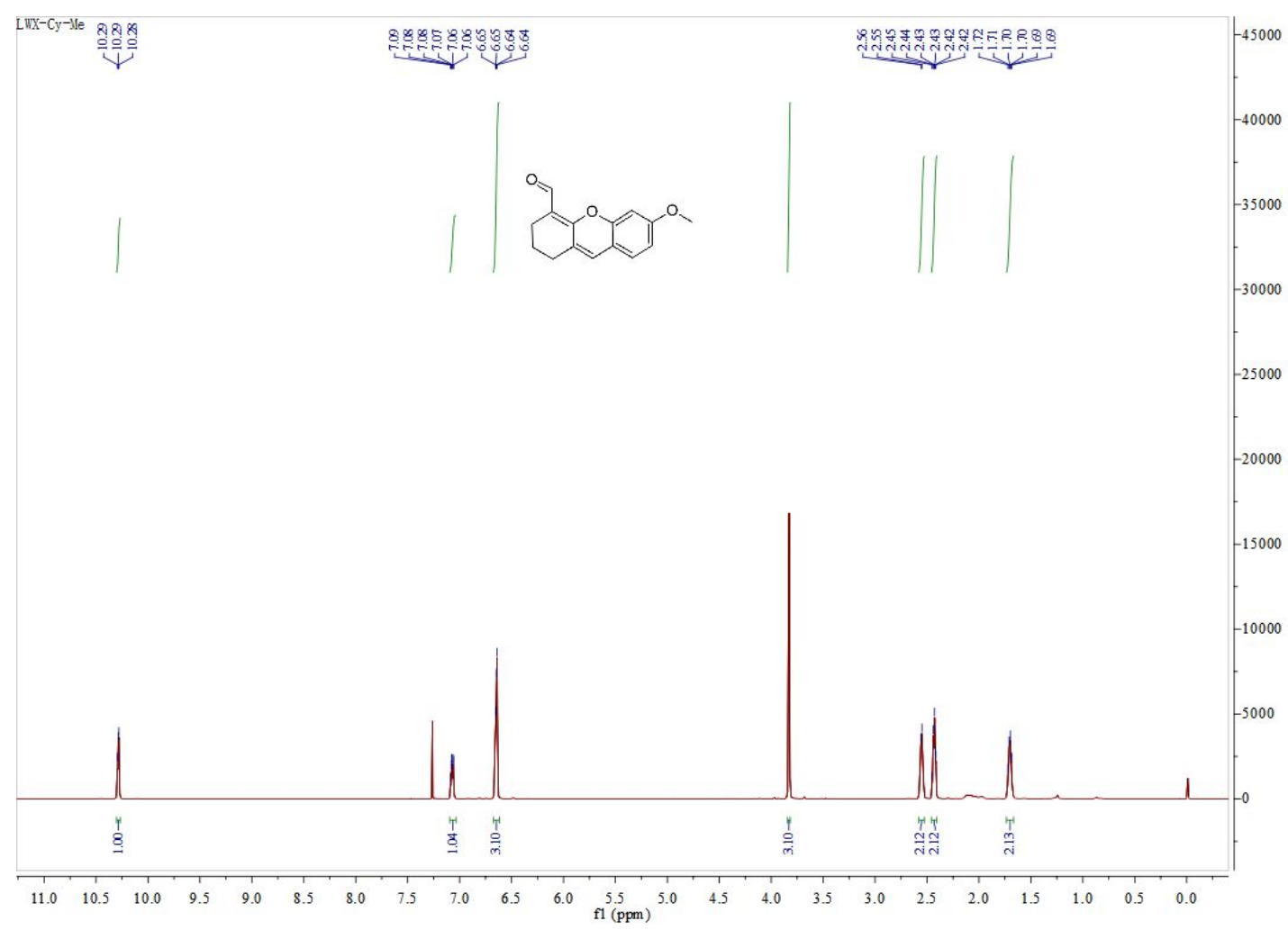

Figure S13. ${ }^{1} \mathrm{H}$ NMR spectrum of Compound 2 in $\mathrm{CDCl}_{3}$.

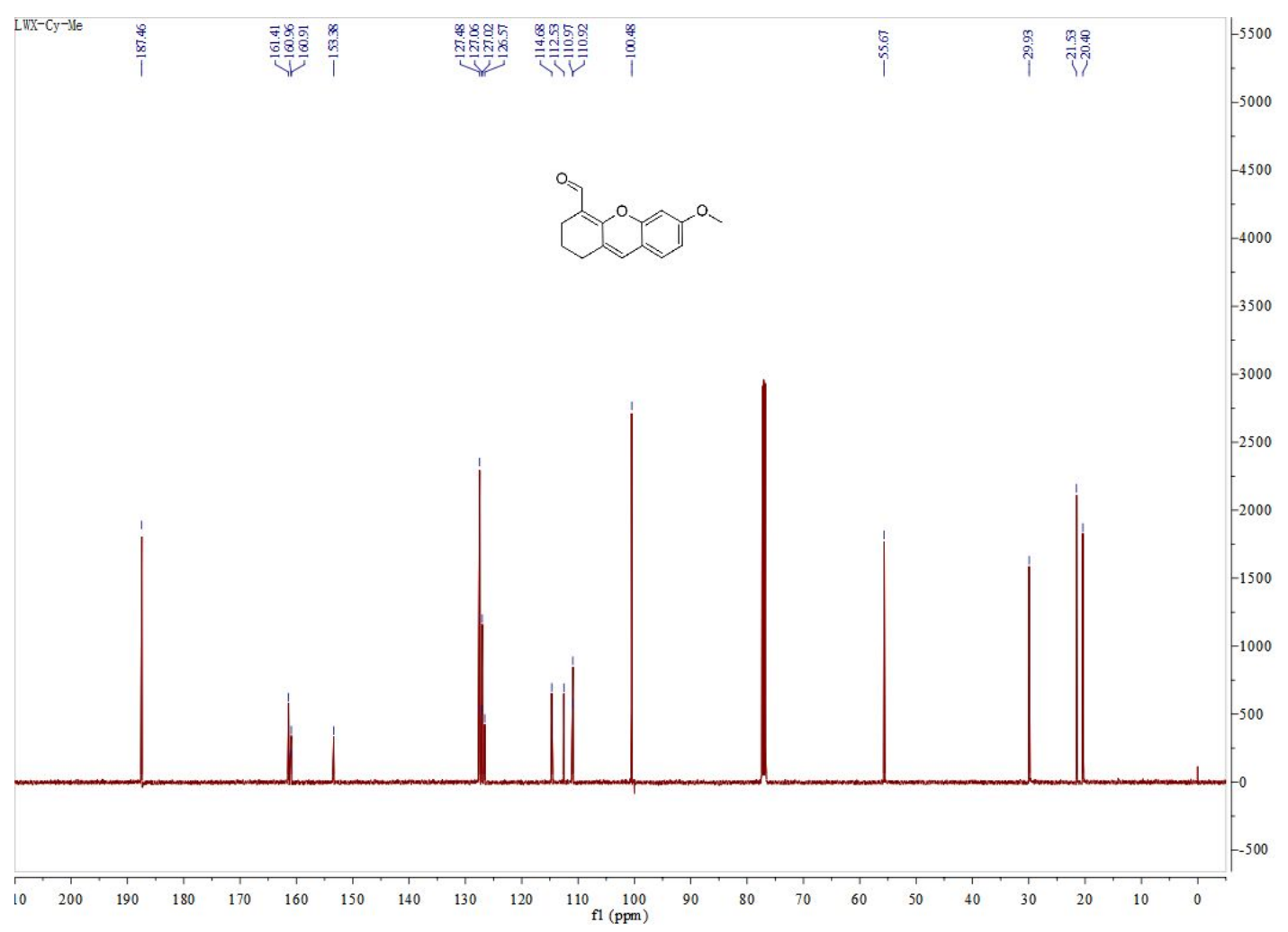

Figure S14. ${ }^{13} \mathrm{C}$ NMR spectrum of 2 in $\mathrm{CDCl}_{3}$. 


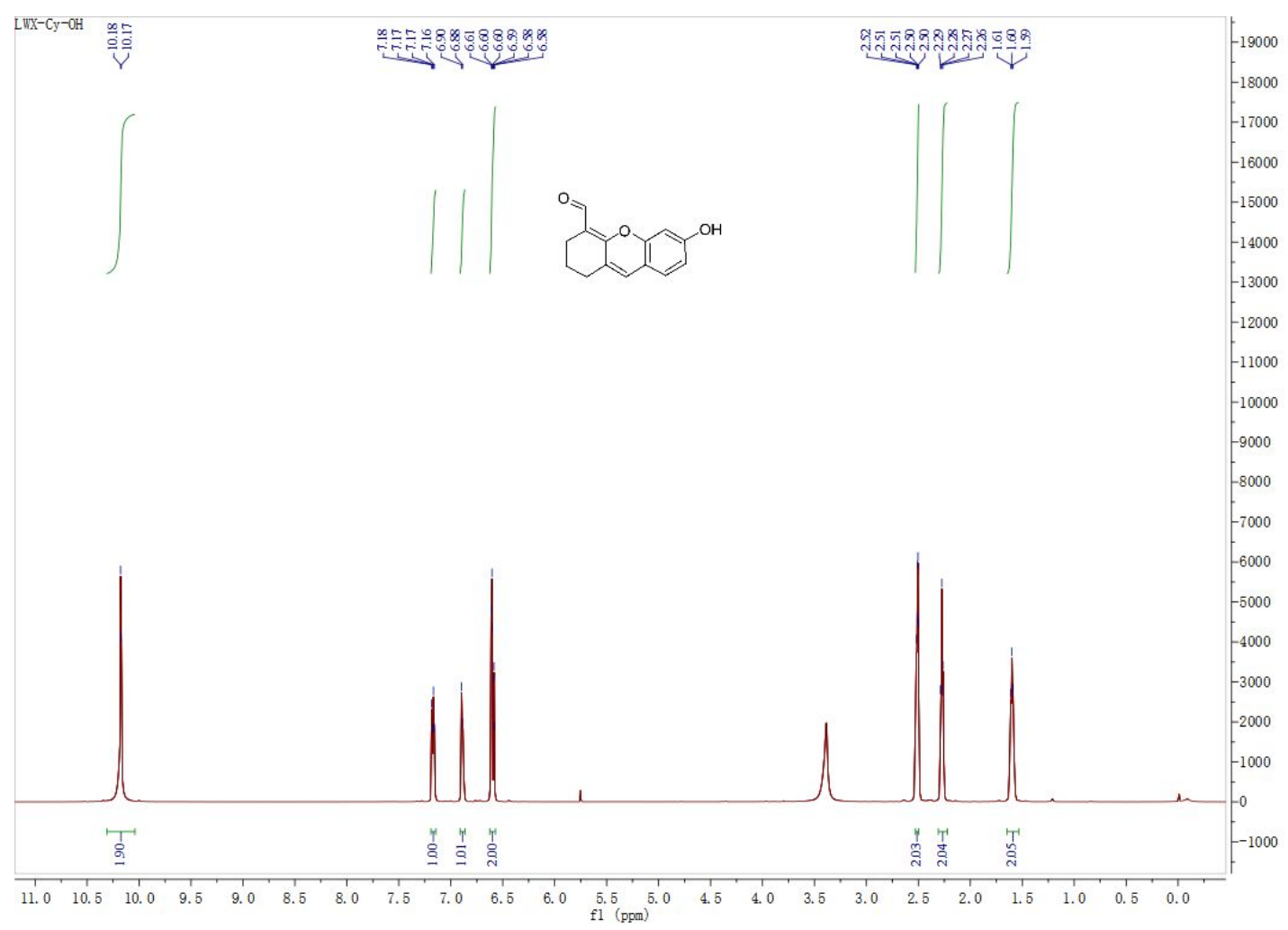

Figure S15. ${ }^{1} \mathrm{H}$ NMR spectrum of Compound 3 in DMSO- $d 6$.

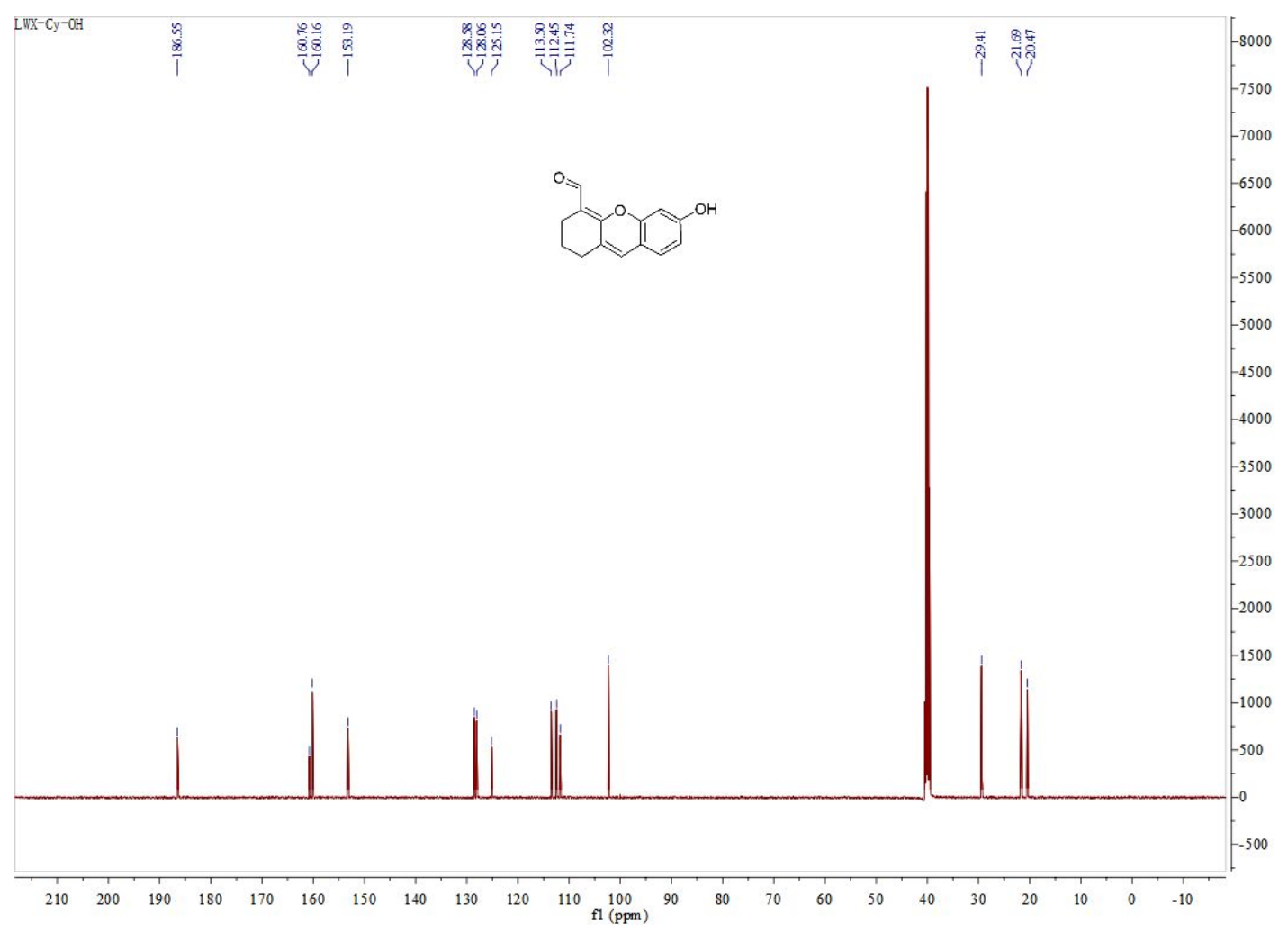

Figure S16. ${ }^{13} \mathrm{C}$ NMR spectrum of Compound 3 in DMSO- $d 6$. 


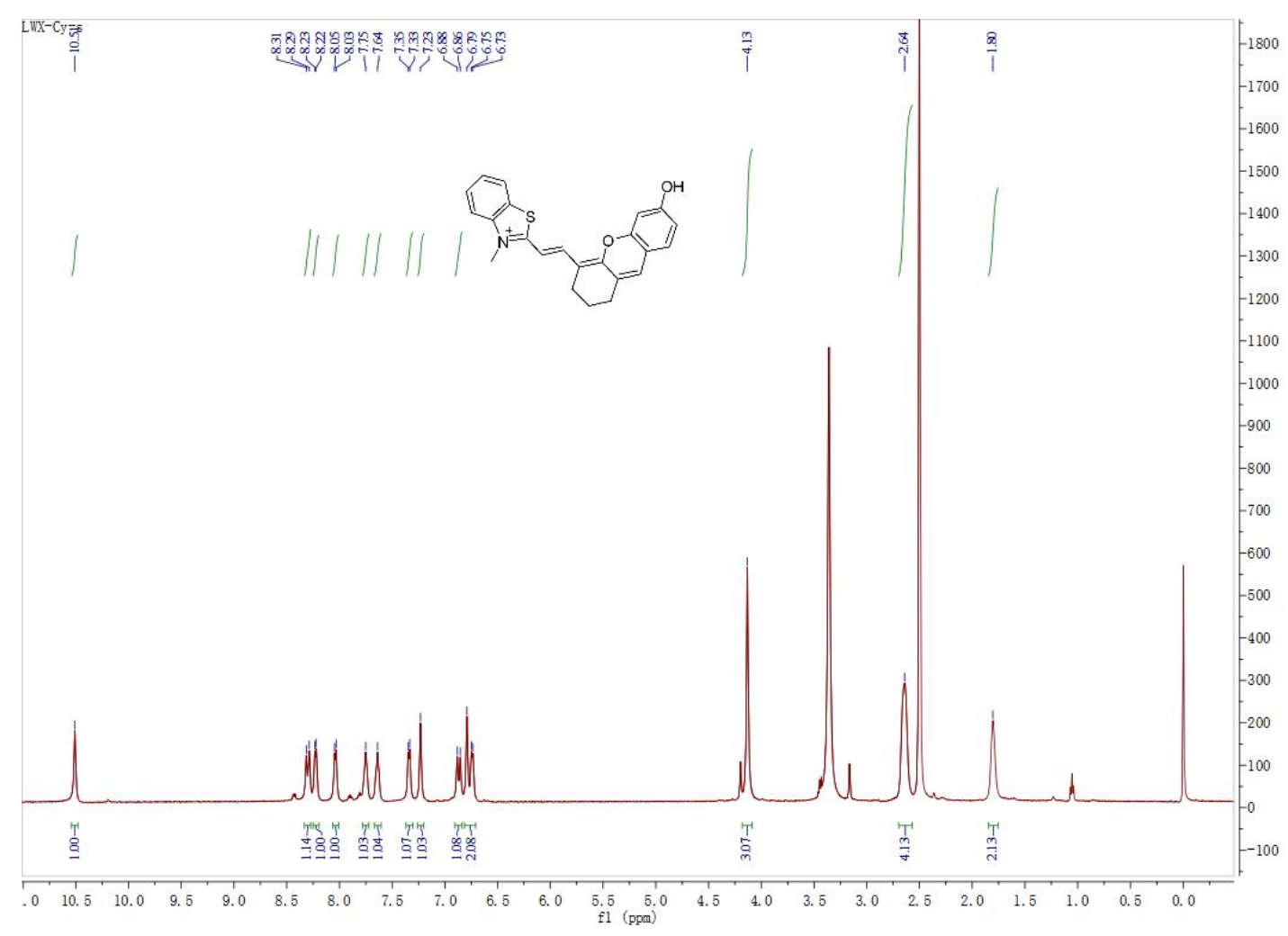

Figure S17. ${ }^{1} \mathrm{H}$ NMR spectrum of Compound MTR-OH in DMSO-d6.

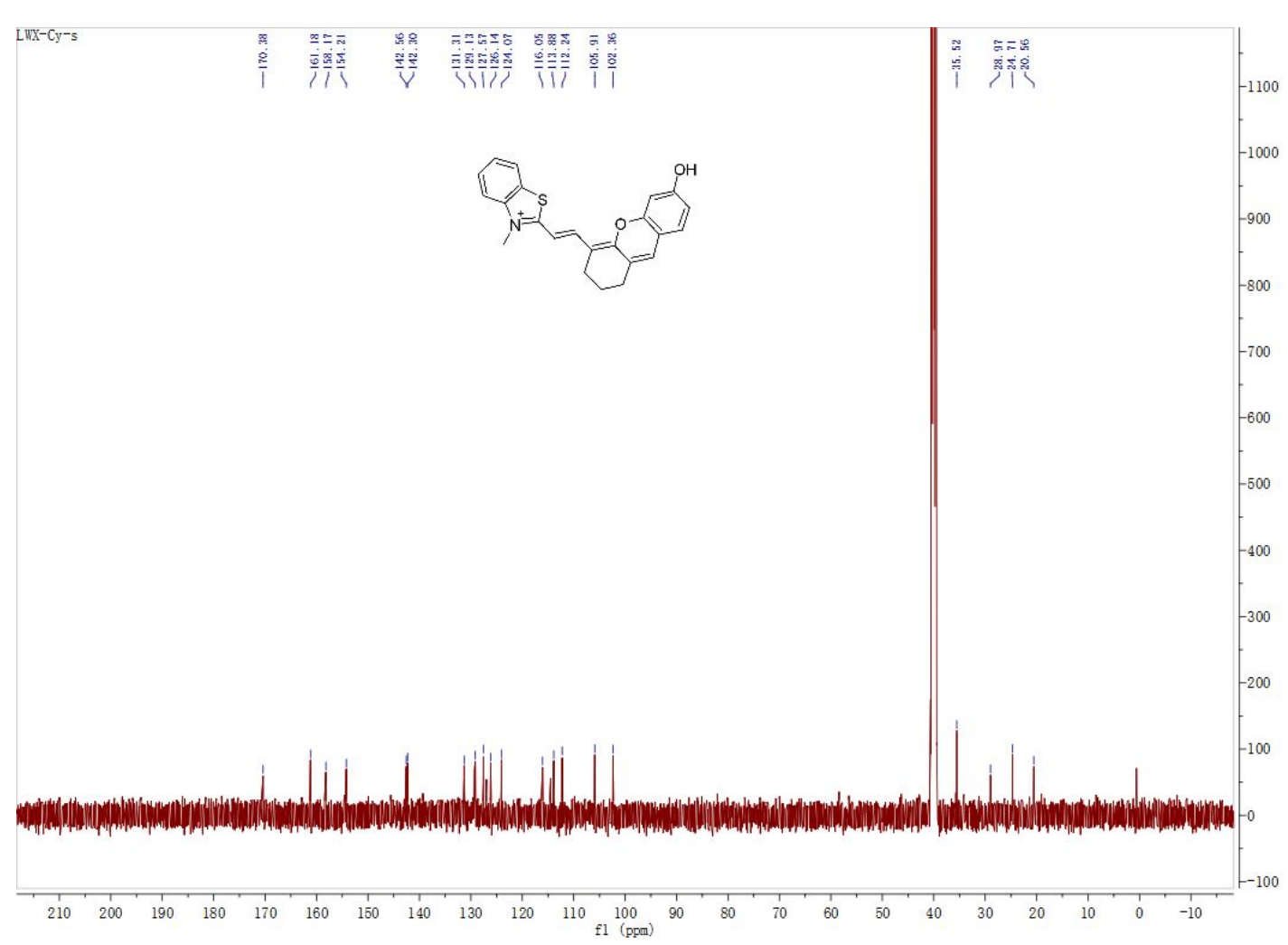

Figure S18. ${ }^{13} \mathrm{C}$ NMR spectrum of Compound MTR-OH in DMSO- $d 6$. 


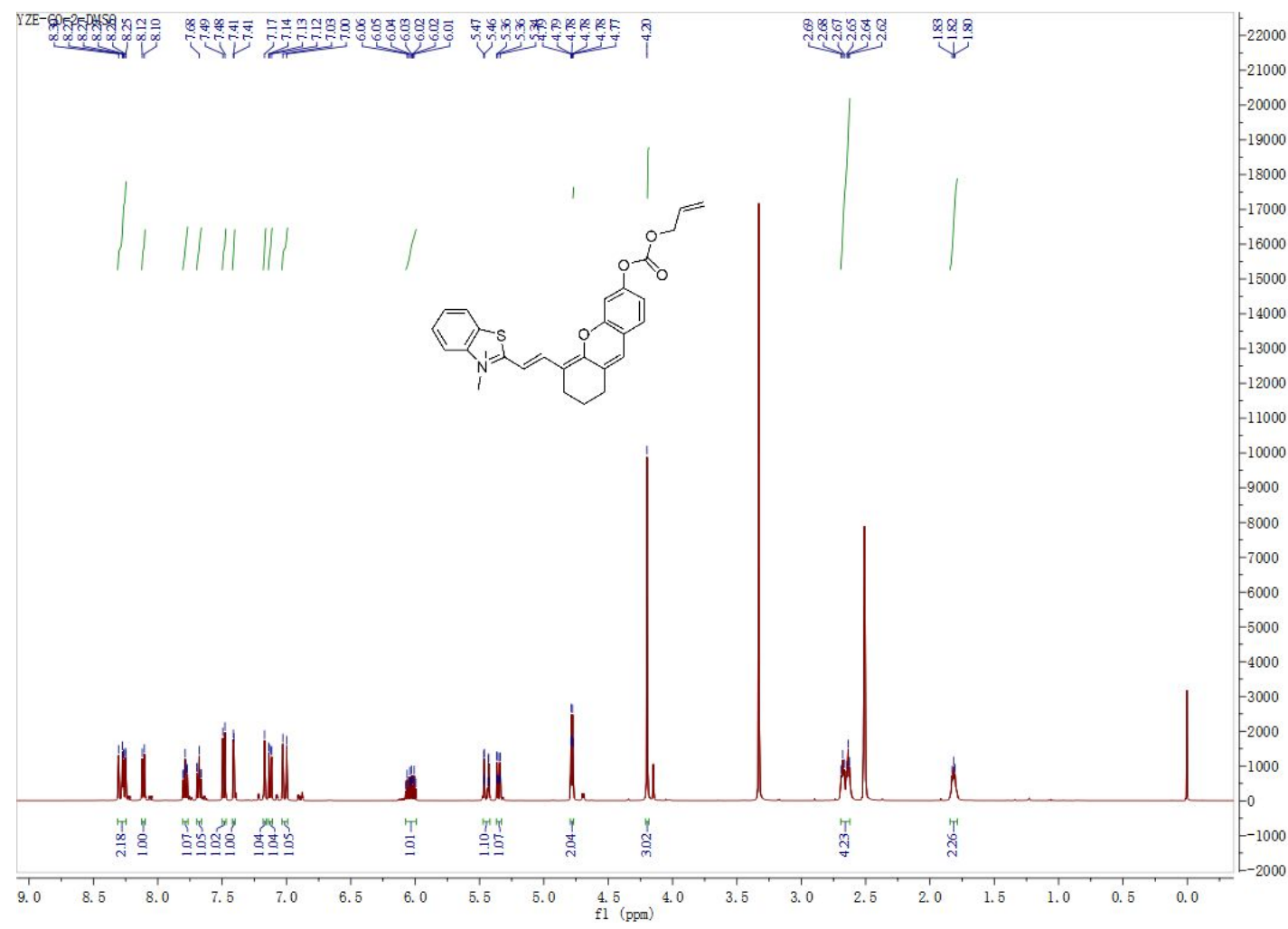

Figure S19. ${ }^{1} \mathrm{H}$ NMR spectrum of Compound MTR-CO in DMSO- $d 6$.

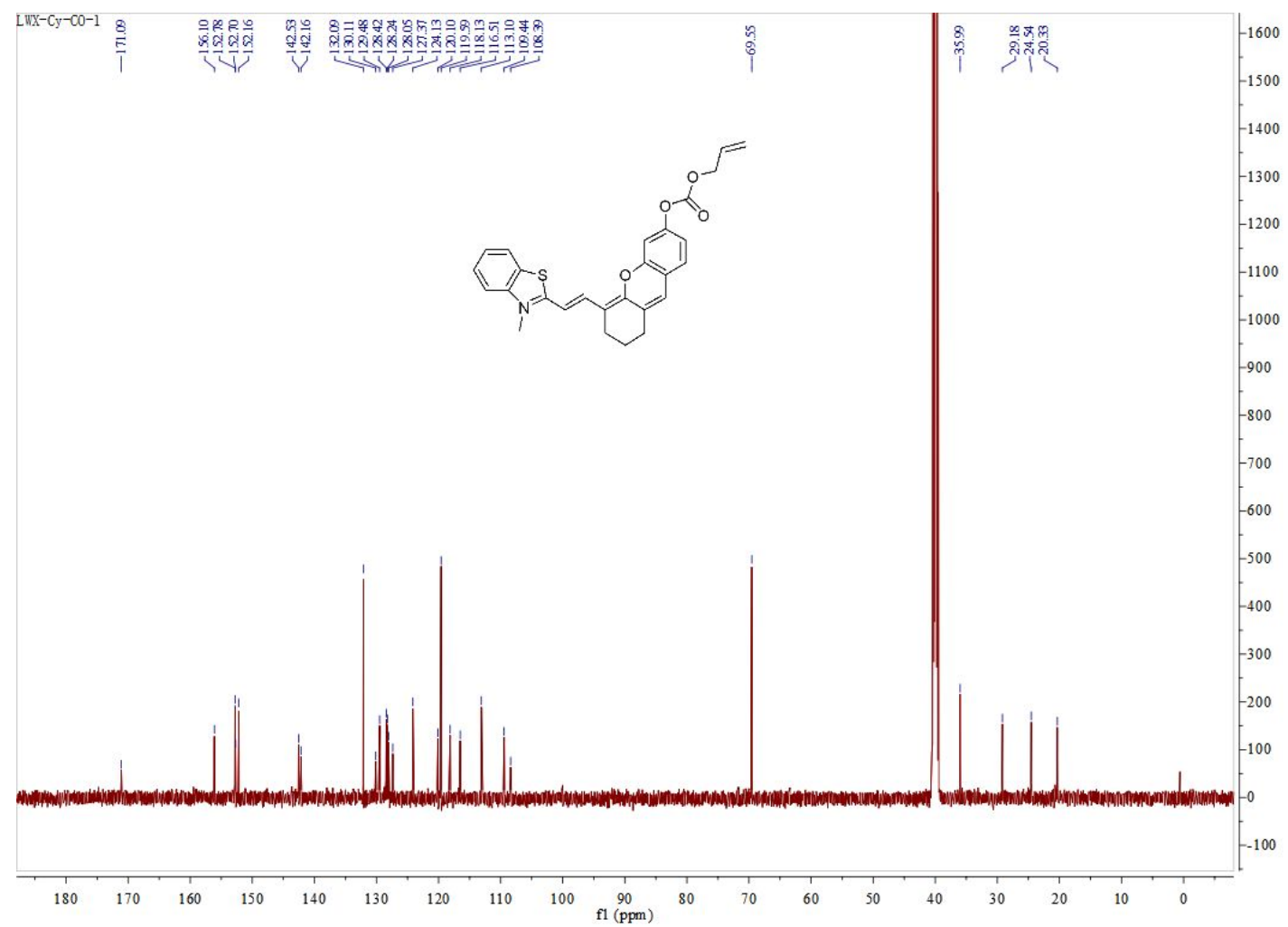

Figure S20. ${ }^{13} \mathrm{C}$ NMR spectrum of Compound MTR-CO in DMSO- $d 6$. 


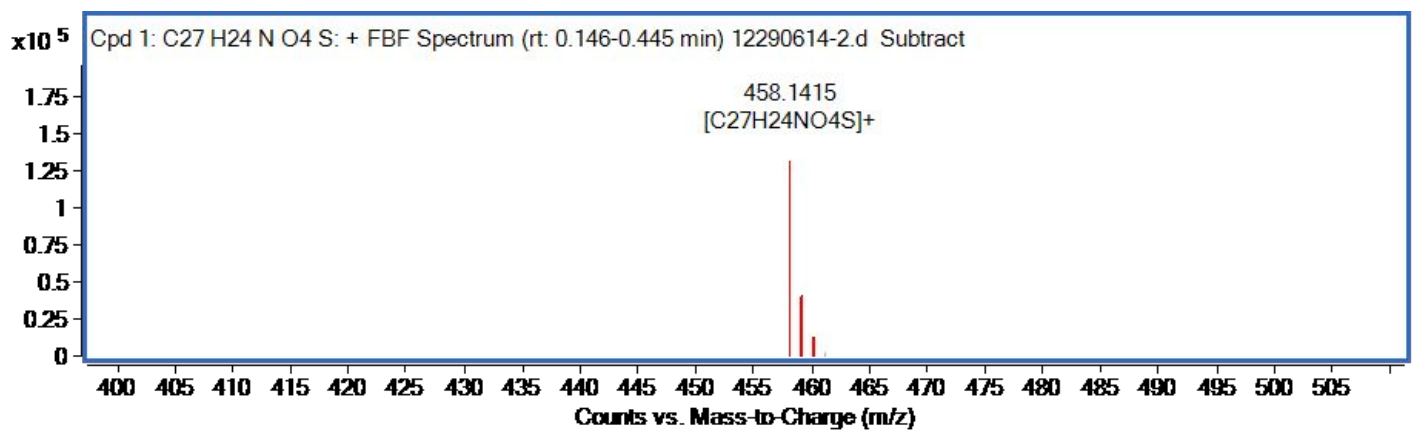

Figure S21. HR-MS spectrum of MTR-CO. 